\title{
Konsekwencje brexitu w dziedzinie prawa prywatnego międzynarodowego
}

\begin{abstract}
Brexit is a unique phenomenon as no Member State has ever expressed the will to leave the European Union. Never before had the in-depth impact of a Member State withdrawal been analysed. The issue has started to be analysed after the referendum in which the British voted in favour of leaving the European Union. The topic of the potential consequences of Brexit in the field of private international law concerns, inter alia, national jurisdiction in civil and commercial matters, mutual recognition and enforcement of judgments, specific procedures of EU uniform law, judicial cooperation between Member States or the functioning of the e-Justice Portal and dynamic forms. Before a given Member State withdraws from the EU, interested parties should have been informed, inter alia, of how pending proceedings will be conducted starting with the withdrawal day, what about proceedings initiated at the date of withdrawal or later on, and what about the rulings of the courts of the applicant state covered by the exequatur procedure before the withdrawal. Therefore, the primary purpose of the article is to determine the framework for the future relationship between the EU and the UK in the field of private international law. An additional aim of this paper is to better prepare natural and legal persons for the new post-Brexit reality. European integration has brought Europe peace and prosperity and enabled unprecedented cooperation in all areas of common interest. Following the withdrawal decision, the state and its citizens cease to benefit from the acquis communautaire. In fact, the United Kingdom left the European Union on 31 January 2020. As far as private international law is concerned, the United Kingdom has become a third country. Subsequently, on 1 February 2020 a transition period has started and it aims to provide more time for citizens and businesses to adapt.
\end{abstract}

a) Dr hab., profesor UG, Zakład Prawa Prywatnego Międzynarodowego Wydziału Prawa i Administracji Uniwersytetu Gdańskiego. 
The negotiations on the future partnership between the EU and the UK has started in March 2020, but they were postponed due to the coronavirus COVID-19 pandemic. The relationship between the United Kingdom and the European Union is sometimes compared to love that has passed away, but former lovers must continue to meet from time to time to manage certain common affaires. The analysis of the topic leads to the conclusion that, in fact, Brexit is a unique phenomenon that has no added value.

Keywords: European Union, withdrawal from the European Union, art. 50 TEU, Brexit, EU uniform law, European private international law, national jurisdiction in civil and commercial matters, mutual recognition and enforcement of judgments, judicial cooperation between Member States, e-Justice Portal

\section{Wprowadzenie}

Brexit jest zjawiskiem unikatowym, nigdy wcześniej bowiem żadne państwo nie wyraziło woli wystąpienia z Unii Europejskiej. Nigdy też nawet nie analizowano dogłębnie skutków wystapienia państwa z Unii Europejskiej. Uczyniono to dopiero po tym, gdy Brytyjczycy po 44 latach członkostwa zagłosowali w referendum za wystapieniem z Unii Europejskiej. Życie pisze niespotykane dotąd scenariusze, stąd temat potencjalnych skutków brexitu w obszarze prawa prywatnego międzynarodowego. Dotyczą one m.in.: jurysdykcji krajowej w sprawach cywilnych i handlowych, uznawania i wykonywania orzeczeń, każdej ze szczególnych procedur unijnego prawa jednolitego, procedury współpracy sądowej między państwami członkowskimi czy funkcjonowania portalu e-Sprawiedliwość i interaktywnych formularzy. Zanim dane państwo wystapi z Unii Europejskiej, zainteresowane podmioty powinny być poinformowane m.in. o tym, jak będa prowadzone postępowania zawisłe w dniu wystąpienia, postępowania wszczęte począwszy od dnia wystąpienia oraz co z orzeczeniami sądów państwa występującego w przypadku, gdy orzeczenia te zostały objęte procedura exequatur przed wystąpieniem. Głównym celem artykułu jest analiza potencjalnych skutków brexitu w obszarze prawa prywatnego międzynarodowego, w szczególności ustalenie zasad przyszłych stosunków prawnych między podmiotami pochodzącymi ze Zjednoczonego Królestwa a podmiotami pochodzącymi z państw członkowskich UE. Jednocześnie publikacja ta służy lepszemu przygotowaniu osób fizycznych i prawnych do nowej pobrexitowej rzeczywistości prawnej. Temat jest godny analizy, ponieważ przedstawia z jednej strony konieczność przygotowania wszystkich zainteresowanych do wystąpienia, a z drugiej - rozmiar tych przygotowań w zakresie zmian w prawie UE, w prawie państw członkowskich i w prawie państwa występującego. 


\section{Geneza i negocjacje procesu wystąpienia}

Geneza i przebieg negocjacji w ramach procesu wystapienia Zjednoczonego Królestwa z Unii Europejskiej maja kluczowe znaczenie dla przyszłych stosunków prawnych między podmiotami pochodzącymi z tego państwa a podmiotami pochodzącymi z państw członkowskich. Proces wystąpienia Zjednoczonego Królestwa z Unii Europejskiej rozpoczą się 23 czerwca 2016 r., gdy Brytyjczycy zagłosowali w referendum za wystąpieniem z Unii Europejskiej. Następnie 29 marca 2017 r. Zjednoczone Królestwo formalnie notyfikowało zamiar wystapienia Radzie Europejskiej ${ }^{1}$, a miesiąc później Rada Europejska zgromadzona na nadzwyczajnym szczycie przyjęła wytyczne określające ramy negocja$\mathrm{cji}^{2}$. Na wstępie, po pierwsze, państwa członkowskie wyraziły wolę, by po wystąpieniu z Unii Europejskiej Zjednoczone Królestwo zachowało status bliskiego partnera. Po drugie, ustalono, że każde porozumienie ze Zjednoczonym Królestwem będzie musiało opierać się na równowadze praw i obowiązków oraz zapewniać równe warunki działania. Po trzecie, podkreślono konieczność zachowania jedności wspólnego rynku, co oznacza, że cztery swobody są niepodzielne, i wykluczono wszelką możliwość podejścia wybiórczego czy sektorowego. Wyraźnie zaznaczono, że państwa nienależące do Unii Europejskiej nie moga mieć takich samych praw ani czerpać takich samych korzyści, jak jej członkowie. Dodatkowo wskazano, że Unia Europejska zachowa swoją autonomię w odniesieniu do podejmowania decyzji, a ponadto niezmieniona pozostanie rola Trybunału Sprawiedliwości Unii Europejskiej. Przyjęto, że pojedyncze elementy nie mogą być ustalane oddzielnie, w myśl zasady, że nic nie jest uzgodnione, dopóki wszystko nie jest uzgodnione. Na koniec ustalono, że Unia Europejska przystąpi do negocjacji z ujednoliconymi stanowiskami, a poszczególne jej państwa nie będą prowadziły oddzielnych negocjacji ze Zjednoczonym Królestwem w kwestiach dotyczących jego wystąpienia z Unii Europejskiej ${ }^{3}$.

Z brzmienia wstępnych ram negocjacji można odnieść wrażenie, że przywódcy państw członkowskich Unii Europejskiej w wystąpieniu Zjednoczonego Królestwa dostrzegli zagrożenie dla jedności Unii, dlatego za wszelką cenę chcieli podkreślić jej niepodzielność, mimo kryzysów, z któ-

${ }^{1}$ United Kingdom notification under Article 50 TEU - A letter of 29 March 2017 from the Prime Minister of the United Kingdom to the President of the European Council, Brussels, 29 March 2017, BXT 1, XT 20001/17.

${ }^{2}$ Rada Europejska, Wytyczne opracowane w następstwie notyfikacji złożonej przez Zjednoczone Królestwo na mocy art. 50 TUE, s. 2, BXT 10, EUCO XT 20004/17.

${ }^{3}$ Ibidem. 
rymi musi się mierzyć. Szok wywołany wizją brexitu skłonił decydentów do pogłębionej refleksji nad tym, w którym kierunku mógłby rozwijać się unijny porządek prawny i obywatelstwo Unii. Spotyka się poglądy, że jedynie stworzenie silnego społeczeństwa europejskiego może uchronić obywateli Unii i obywatelstwo Unii od fragmentacji w ramach unijnego porządku prawnego. W konsekwencji fragmentacja wywołana brexitem wymagała przyjęcia rozwiązań prawnych gwarantujących ochronę praw i statusu obywateli Unii w Zjednoczonym Królestwie oraz obywateli brytyjskich w Unii Europejskiej. ${ }^{4}$ W odniesieniu do prawa prywatnego międzynarodowego wśród specjalistów pojawiały się argumenty, że najlepszym rozwiązaniem zarówno dla Zjednoczonego Królestwa, jak i dla Unii Europejskiej byłoby uzgodnienie dalszego stosowania istniejących instrumentów prawa UE lub dążenie do zawarcia nowej umowy, która ściśle powiela te instrumenty ${ }^{5}$.

Z tego też względu warunki wystapienia Zjednoczonego Królestwa z Unii Europejskiej stanowiły przedmiot szczegółowych negocjacji, których nadrzędnym celem było doprowadzenie do ratyfikacji umowy o wystąpieniu. Wystąpienie bez jakiejkolwiek umowy określane jest mianem twardego brexitu, ponieważ w takim przypadku Zjednoczone Królestwo stałoby się państwem trzecim we wszystkich obszarach integracji. Spowodowałoby to zakłócenia w funkcjonowaniu przedsiębiorców, ale także o wiele większe utrudnienia $\mathrm{w}$ życiu obywateli, znacznie większe niż w przypadku zawarcia umowy o wystapieniu. Optymalne przygotowanie do wystapienia miało więc znaczenie nie tylko dla władz krajowych czy samej Unii Europejskiej, lecz przede wszystkim dla podmiotów prywatnych. Pierwsza umowę ${ }^{6}$ wynegocjowała brytyjska premier Theresa May, ale umowa nie zyskała aprobaty brytyjskiego parlamentu. Kolejna umowa, która była zmieniona wersja pierwszej umowy, została wynegocjowana przez premiera Borisa Johnsona.

Efektem negocjacji prowadzonych we wrześniu i październiku $2019 \mathrm{r}$. było porozumienie odnoszace się do zmienionego tekstu Protokołu w sprawie Irlandii/Irlandii Północnej, zawartego w umowie o wystąpieniu, oraz

${ }^{4}$ O. Garner: After Brexit: Protecting European Citizens and Citizenship from Fragmentation (2016), European University Institute Department of Law Working Paper No. 2016/22. Available at SSRN, https://ssrn.com/abstract=2871404 or http://dx.doi. org/10.2139/ssrn.2871404 [Dostęp: 25.10.2019 r.].

${ }^{5}$ G. Rühl: Judicial Cooperation in Civil and Commercial Matters after BREXIT: Which Way Forward? „International and Comparative Law Quarterly” 2016, 67(1), 99128. doi:10.1017/S0020589317000574 [Dostęp: 25.10.2019 r.].

${ }^{6}$ Decyzja Rady (UE) 2019/274 z dnia 11 stycznia 2019 r. w sprawie podpisania, w imieniu Unii Europejskiej i Europejskiej Wspólnoty Energii Atomowej, umowy o wystąpieniu Zjednoczonego Królestwa Wielkiej Brytanii i Irlandii Północnej z Unii Europejskiej i Europejskiej Wspólnoty Energii Atomowej. Dz.Urz. UE L 47 I, 19.02.2019, s. 1. 
co do koniecznych dostosowań technicznych art. 184 i 185 umowy o wystąpieniu. W dniu 17 października 2019 r. Rada Europejska zatwierdziła zmienioną umowę o wystąpieniu i zaakceptowała zmieniony tekst deklaracji politycznej, a 21 października 2019 r. Rada przyjęła decyzję (UE) 2019/1750 zmieniająca decyzję (UE) 2019/274 (5) w sprawie podpisania umowy o wystąpieniu ${ }^{7}$. W dniu 19 października 2019 r. Zjednoczone Królestwo wystapiło z wnioskiem o przedłużenie okresu, o którym mowa w art. 50 ust. 3 TUE, do dnia 31 stycznia 2020 r. Rada Europejska wyraziła zgodę na ponowne przedłużenie terminu wystapienia do dnia 31 stycznia 2020 r. celem umożliwienia zakończenia ratyfikacji umowy o wystąieniu ${ }^{8}$. Tymczasem 12 grudnia 2019 r. odbyły się przedterminowe wybory do Izby Gmin Zjednoczonego Królestwa Wielkiej Brytanii i Irlandii Północnej, w wyniku których Partia Konserwatywna odzyskała w Izbie Gmin większość bezwzględną. W dniu 9 stycznia 2020 r. Izba Gmin zatwierdziła projekt ustawy o porozumieniu w sprawie wystąpienia Zjednoczonego Królestwa z Unii Europejskiej (Withdrawal Agreement Bill - WAB) ${ }^{9}$. Tym samym ostatnia przeszkoda na drodze do brexitu została pokonana.

Od tej pory droga Zjednoczonego Królestwa do wystąpienia z Unii Europejskiej nabrała tempa. W dniu 24 stycznia 2020 r. w imieniu Unii umowę o wystapieniu podpisali przewodniczący Rady Europejskiej Charles Michel i przewodniczaca Komisji Europejskiej Ursula von der Leyen, a w imieniu Zjednoczonego Królestwa premier Boris Johnson. Następnie 29 stycznia 2020 r. Zjednoczone Królestwo potwierdziło, że ratyfikowało umowę o wystąpieniu oraz poinformowało władze Unii Europejskiej o zakończeniu wewnętrznych procedur niezbędnych do wejścia w życie umowy brexitowej. Tego samego dnia wymienioną umowę zatwierdził Parlament Europejski na posiedzeniu plenarnym. Rada przyjęła decyzję o zawarciu w imieniu Unii umowy brexitowej w dniu 30 stycznia 2020 r., co było równoznaczne $\mathrm{z}$ ratyfikowaniem umowy w imieniu UE. Ostatecznie umowa o wystapieniu weszła w życie 31 stycznia 2020 r. o północy, co stanowi jednocześnie koniec okresu, o którym mowa w art. 50

${ }^{7}$ Decyzja Rady (UE) 2019/1750 z dnia 21 października 2019 r. zmieniająca decyzję (UE) 2019/274 w sprawie podpisania, w imieniu Unii Europejskiej i Europejskiej Wspólnoty Energii Atomowej, umowy o wystąpieniu Zjednoczonego Królestwa Wielkiej Brytanii i Irlandii Północnej z Unii Europejskiej i Europejskiej Wspólnoty Energii Atomowej. Dz.Urz. UE L 274 I, 28.10.2019, s. 1.

${ }^{8}$ Decyzja Rady Europejskiej (UE) 2019/1810 przyjęta w porozumieniu ze Zjednoczonym Królestwem z dnia 29 października 2019 r. przedłużająca okres, o którym mowa w art. 50 ust. 3 TUE, XT/20024/2019/REV/2. Dz.Urz. UE L 278 I, 30.10.2019, s. 1-3.

${ }_{9}$ Bill stages - European Union (Withdrawal Agreement) Bill 2019-20, https://ser vices.parliament.uk/Bills/2019-20/europeanunionwithdrawalagreement/stages.html [Dostęp: 19.01.2020 r.]. 
ust. 3 TUE $^{10}$. Od tego momentu Zjednoczone Królestwo przestało być państwem członkowskim UE i jest uważane za państwo trzecie, jeśli chodzi o prawo UE. Z dniem 1 lutego 2020 r. rozpoczą się okres przejściowy, który pierwotnie zaplanowano do 31 grudnia 2020 r. Okres ten może zostać przedłużony o rok lub dwa lata, ale ewentualna decyzja o przedłużeniu okresu przejściowego musiałaby zapaść przed 1 lipca $2020 \mathrm{r}$. $\mathrm{Na}$ początku marca 2020 r. rozpoczęto negocjacje w sprawie przyszłego partnerstwa ze Zjednoczonym Królestwem, jednak rozmowy opóźniły się ze względu na wybuch pandemii COVID-19. Wśród setek tysięcy zakażonych koronawirusem znaleźli się m.in.: Michel Barnier — główny negocjator brexitu z ramienia UE, oraz Boris Johnson - premier Wielkiej Brytanii. Jeszcze na początku marca 2020 r. premier Boris Johnson kategorycznie sprzeciwiał się przedłużaniu okresu przejściowego, ale wybuch pandemii COVID-19 przyniósł niepewność co do przyszłości także w tej kwestii.

W okresie przejściowym, o ile w umowie o wystapieniu nie przewidziano inaczej, prawo Unii ma nadal zastosowanie do Zjednoczonego Królestwa i na jego terytorium. Dotyczy to całego dorobku prawnego UE, w tym umów międzynarodowych. Niemniej jednak Zjednoczone Królestwo nie uczestniczy już $\mathrm{w}$ procesie zarządzania ani $\mathrm{w}$ procesie decyzyjnym instytucji, organów i jednostek organizacyjnych UE. Trwające mandaty członków instytucji, organów i jednostek organizacyjnych Unii powołanych, mianowanych lub wybranych w związku z członkostwem Zjednoczonego Królestwa w Unii wygasły z chwila, gdy traktaty przestały mieć zastosowanie do Zjednoczonego Królestwa, czyli z dniem jego wystąienia $^{11}$. Na marginesie rozważań warto przypomnieć, że Zjednoczone Królestwo nie zaproponowało kandydata na stanowisko członka Komisji Europejskiej powołanej w listopadzie 2019 r., mimo wynikajacego z prawa Unii obowiązku przedstawienia kandydata ${ }^{12}$. Okres przejściowy ma zapewnić czas na przygotowanie się do dnia, w którym prawo Unii przestanie mieć zastosowanie do Zjednoczonego Królestwa i na jego terytorium $^{13}$.

${ }^{10}$ Artykuł 50 ust. 3 TUE: „Traktaty przestają mieć zastosowanie do tego Państwa od dnia wejścia w życie umowy o wystąpieniu [...]”.

${ }^{11}$ Ibidem, motyw 12 preambuły do wyżej wymienionej decyzji.

${ }_{12}$ Decyzja Rady Europejskiej (UE) 2019/1989 z dnia 28 listopada 2019 r. w sprawie mianowania Komisji Europejskiej, ST/34/2019/INIT, motywy 7-9 preambuły do wyżej wymienionej decyzji. Dz.Urz. UE L 308, 29.11.2019, s. 100—102.

${ }^{13}$ Wytyczne Rady Europejskiej (art. 50) w sprawie ram przyszłych stosunków UE - Wielka Brytania (23 marca 2018), EUCO XT 20001/18, BXT 25. Bruksela, 23 marca 2018 r., s. 2. 


\section{Zawiadomienia dotyczące gotowości na brexit}

Równolegle do negocjacji w sprawie umowy o wystapieniu instytucje Unii Europejskiej publikowały zawiadomienia dotyczące gotowości na brexit, inicjatywy ustawodawcze i informacje na temat innych działań przygotowawczych. Zawiadomienia dotyczące gotowości na brexit zawierały informacje dyrekcji generalnych Komisji Europejskiej na temat tego, w jaki sposób brexit może wpłynąc na prawo i politykę w ich obszarach działań. Inicjatywy ustawodawcze obejmowały proponowane środki ustawodawcze i inne akty prawne zapewniające funkcjonowanie przyszłych ram prawnych UE-27 po wystapieniu Zjednoczonego Królestwa z UE. Z kolei w ramach tzw. innych działań przygotowawczych prezentowano dodatkowe prace administracyjne i techniczne w zakresie gotowości i planowania awaryjnego, komunikaty i seminaria przygotowawcze grupy roboczej Rady ds. art. 50. Ponadto udostępnione zostały linki do krajowych stron związanych z brexitem oraz do innych środków gotowości w państwach członkowskich ${ }^{14}$. Komisja Europejska publikowała także szczegółowe informacje na temat praw pobytu obywateli Wielkiej Brytanii przebywających legalnie na terytorium UE-27 oraz uprawnień do zabezpieczenia społecznego związanych z Wielką Brytanią w przypadku braku umowy ${ }^{15}$.

Prawo UE w obszarze prawa prywatnego międzynarodowego było przedmiotem jednych z pierwszych zawiadomień dotyczących gotowości na brexit. W toku negocjacji zawiadomienia te były uaktualniane ${ }^{16} . \mathrm{Z}$ zastrzeżeniem okresu przejściowego przewidzianego w ewentualnej umowie o wystapieniu Zjednoczonego Królestwa, od dnia wystąpienia przepisy UE dotyczące wymiaru sprawiedliwości w sprawach cywilnych i prawa prywatnego międzynarodowego nie będą już mieć zastosowania do Zjednoczonego Królestwa. Niesie to z sobą konkretne konsekwencje, nawet jeśli Zjednoczone Królestwo nie w pełni uczestniczy w dorobku prawnym w zakresie współpracy sądowej w sprawach cywilnych i handlowych.

${ }_{14}$ National Brexit information in Member States, https://ec.europa.eu/info/brexit/ brexit-preparedness/national-brexit-information-member-states_pl; polski rząd urucho mił stronę https://www.brexit.gov.pl/.

${ }^{15}$ Citizens' rights: https://ec.europa.eu/info/brexit/brexit-preparedness/citizens-rights_pl.

${ }^{16}$ Komisja Europejska - Dyrekcja Generalna ds. Sprawiedliwości i Konsumentów: Zawiadomienie dla zainteresowanych stron - Wystapienie Zjednoczonego Królestwa $z$ UE a przepisy UE $w$ dziedzinie wymiaru sprawiedliwości $w$ sprawach cywilnych $i$ prawa prywatnego międzynarodowego, REV1 — dokument zastępuje zawiadomienie dla zainteresowanych stron z dnia 21 listopada 2017 r. Bruksela, 18 stycznia 2019 r. 


\section{Jurysdykcja krajowa w sprawach cywilnych i handlowych po wystąpieniu}

Prawo UE ustanawia zharmonizowane normy dotyczace jurysdykcji krajowej w sprawach cywilnych i handlowych, w tym w sprawach dotyczaccych niewypłacalności i prawa rodzinnego ${ }^{17}$. Przepisy te mają zastosowanie jedynie wtedy, gdy pozwany ma miejsce zamieszkania lub siedzibę w państwie członkowskim UE. W kontekście wystąpienia Zjednoczonego Królestwa wyróżnić można dwie kategorie spraw prowadzonych w jednym z państw członkowskich UE-27. Pierwsza grupa spraw obejmuje postępowania, które były zawieszone przed dniem brexitu, a druga — postępowania wszczęte po brexicie. Jeśli chodzi o sprawy zawieszone przed dniem wystąpienia, które będą się nadal toczyć przed sądem jednego z państw członkowskich UE-27 po dniu wystapienia, to przepisy UE dotyczące jurysdykcji krajowej nadal będą miały zastosowanie w przypadku postępowania z udziałem pozwanego majacego miejsce zamieszkania lub siedzibę w Zjednoczonym Królestwie. Jeśli natomiast chodzi o sprawy wszczęte po brexicie w jednym z państw członkowskich UE-27, to przepisy dotyczace jurysdykcji krajowej zawarte w aktach prawnych UE w dziedzinie prawa cywilnego i handlowego oraz prawa rodzinnego nie będą już mieć zastosowania $\mathrm{w}$ przypadku postępowania $\mathrm{z}$ udziałem pozwanego mającego miejsce zamieszkania lub siedzibę w Zjednoczonym Królestwie.

Istnieje możliwość, że w przyszłości przyjęte będą akty prawa UE ustanawiajace przepisy dotyczace jurysdykcji w odniesieniu do państw trzecich i wówczas przepisy te znajdą zastosowanie w wymianie z państwami trzecimi, w tym ze Zjednoczonym Królestwem. Póki co, jeśli chodzi o sprawy wszczęte po dniu brexitu, to jurysdykcja krajowa będzie określana na podstawie przepisów krajowych państwa członkowskiego, w którym wystąpiono do sądu. I tak możliwość wniesienia pozwu przeciwko ubezpieczycielowi ze Zjednoczonego Królestwa przed sąd państwa członkowskiego UE po brexicie będzie zależała od przepisów prawa krajowego. Jeśli chodzi o zasady dotyczace zawisłości sprawy, to od dnia wystąpienia obowiązek sądu państwa członkowskiego UE-27 określony w art. 29 ust. 1 rozporządzenia (UE) nr 1215/2012 nie będzie miał zastosowania w odniesieniu do powództwa wytoczonego przed sądem Zjednoczonego Królestwa. Jeśli natomiast powództwo zostało w pierwszej kolej-

${ }^{17}$ N. Półtorak: Rola Unii Europejskiej w kształtowaniu współczesnego prawa prywatnego międzynarodowego. „Kwartalnik Prawa Prywatnego” 2019, z. 28/2, s. 277—295. 
ności wytoczone przed sądem Zjednoczonego Królestwa, to zastosowanie znajdzie art. 33 rozporządzenia (UE) nr 1215/2012 ${ }^{18}$.

$\mathrm{W}$ niektórych sprawach zastosowanie znajdą konwencje międzynarodowe, w tym konwencje opracowane przez Haska Konferencję Prawa Prywatnego Międzynarodowego, o ile zarówno Unia Europejska lub jej państwa członkowskie, jak i Zjednoczone Królestwo sa stronami danej konwencji ${ }^{19}$. Możliwe sa różnice między stosowaniem konwencji haskich w ramach członkostwa w UE a ich stosowaniem z mocy przystąienia do nich byłego państwa członkowskiego UE. Na przykład w ramach Haskiej Konferencji Prawa Prywatnego Międzynarodowego w dniu 30 czerwca 2005 r. przyjęta została Konwencja o umowach dotyczących właściwości sąu ${ }^{20}$. Chodzi o umowy dotyczące właściwości sądu między stronami międzynarodowych transakcji. Konwencja ta zapewnia stronom niezbędną pewność prawa, która przejawia się przez poszanowanie zawartej przez nie umowy dotyczącej właściwości sądu oraz w tym, że orzeczenie wydane przez wskazany $\mathrm{w}$ niej sąd będzie mogło zostać uznane i wykonane w postępowaniach międzynarodowych ${ }^{21}$. Normuje ona kwestie wcześniej uregulowane wtórnym prawem UE, dotyczącym wyboru właściwości sądu przez strony oraz uznawania i wykonywania orzeczeń wydanych na podstawie takiego wyboru ${ }^{22}$.

Dążąc do zatwierdzenia wyżej wymienionej Konwencji w imieniu Unii, należało w pierwszej kolejności zapewnić spójność pomiędzy przepisami unijnymi $\mathrm{w}$ sprawie wyboru jurysdykcji w sprawach cywilnych i handlowych oraz postanowieniami wymienionej Konwencji ${ }^{23}$. Między

${ }^{18}$ Komisja Europejska - Dyrekcja Generalna ds. Sprawiedliwości i Konsumentów: Pytania i odpowiedzi zwiazane z wystapieniem Zjednoczonego Królestwa z Unii Europejskiej $w$ odniesieniu do wymiaru sprawiedliwości $w$ sprawach cywilnych $i$ prawa prywatnego międzynarodowego. Bruksela, 11 kwietnia 2019 r., s. 3 i n.

${ }^{19}$ Komisja Europejska - Dyrekcja Generalna ds. Sprawiedliwości i Konsumentów: Zawiadomienie dla zainteresowanych stron - Wystapienie Zjednoczonego Królestwa $z$ UE a przepisy UE $w$ dziedzinie wymiaru sprawiedliwości $w$ sprawach cywilnych i prawa prywatnego międzynarodowego..., s. 2.

${ }^{20}$ Konwencja z dnia 30 czerwca 2005 r. o umowach dotyczących właściwości sądu, Sprawozdanie wyjaśniające sporządzone przez Trevora Hartleya i Masato Dogauchi. Wyd. Stałe Biuro Konferencji, Haga 2013, https://assets.hcch.net/docs/4c20f35d-8ee44c97-9040-309e8af56588.pdf [Dostęp: 25.10.2019 r.].

${ }^{21}$ Motyw 2 Decyzji Rady 2014/887/WE z dnia 4 grudnia 2014 r. w sprawie zatwierdzenia, w imieniu Unii Europejskiej, Konwencji haskiej z dnia 30 czerwca 2005 r. o umowach dotyczących właściwości sądu. Dz.Urz. UE L 353, 10.12.2014, s. 5—8.

${ }^{22}$ Rozporządzenie Rady (WE) nr 44/2001 z dnia 22 grudnia 2000 r. w sprawie jurysdykcji i uznawania orzeczeń sądowych oraz ich wykonywania w sprawach cywilnych i handlowych (Bruksela I). Dz.Urz. L 12, 16.01.2001, s. 1-23.

${ }^{23}$ A. Mukarrum, P. Beaumont: Exclusive Choice of Court Agreements: Some Issues on the Hague Convention on Choice of Court Agreements and Its Relationship with 
innymi z tego względu rozporządzenie $\mathrm{nr}$ 44/2001 (Bruksela I) zastapiono rozporządzeniem 1215/2012 ${ }^{24}$ (Bruksela I wersja przekształcona $)^{25}$. Następnie Unia Europejska oświadczyła, że posiada kompetencje we wszystkich sprawach uregulowanych $\mathrm{w}$ tej Konwencji ${ }^{26}$ i podpisała ją, a państwa członkowskie zostały związane Konwencja w wyniku jej zatwierdzenia przez Unię ${ }^{27}$. Konwencja ma zastosowanie we wszystkich sprawach, w których co najmniej jedna ze stron ma miejsce pobytu w umawiającym się państwie innym niż państwo członkowskie UE, natomiast rozporządzenie ma zastosowanie, gdy co najmniej jedna strona ma miejsce zamieszkania $\mathrm{w}$ państwie członkowskim ${ }^{28}$. Jednym z państw związanych wymienioną Konwencją na mocy decyzji Rady było Zjednoczone Królestwo. Wobec woli wystąpienia z UE Zjednoczone Królestwo w dniu 28 grudnia 2018 r. złożyło wniosek o przystapienie do tej Konwencji. Wejdzie ona w życie w Zjednoczonym Królestwie w dniu brexitu bez umowy lub w dniu brexitu z umowa, która nie reguluje tej kwestii, co jest w tym zakresie równoznaczne $\mathrm{z}$ wystapieniem bez umowy.

Konkludując, ta sama konwencja będzie wiązała Zjednoczone Królestwo na innych podstawach prawnych przed wystąpieniem i po wystąieniu bez umowy. Zasadniczo w dniu wystapienia bez umowy konwencja, na podstawie której sporządzona została dana umowa, przestaje mieć zastosowanie do Zjednoczonego Królestwa. Ponadto wymieniona Konwencja ma zastosowanie do umów o wyłączną właściwość sądu zawartych po jej wejściu w życie w państwie wybranego sądu i nie ma zastosowania do postępowań wszczętych przed jej wejśsiem w życie w państwie sądu, przed którym wszczęto postępowanie ${ }^{29}$. Niemniej jednak Zjednoczone Królestwo deklaruje, że zadba o to, by zapewniona była ciagłość

the Brussels I Recast Especially Anti-Suit Injunctions, Concurrent Proceedings and the Implications of BREXIT. „Journal of Private International Law” vol. 13, no. 2, Aug. 2017, s. 386-410. EBSCOhost, doi:10.1080/17441048.2017.1348782 [Dostęp: 25.10.2019 r.].

${ }^{24}$ Rozporządzenie Parlamentu Europejskiego i Rady (UE) nr 1215/2012 z dnia 12 grudnia 2012 r. w sprawie jurysdykcji i uznawania orzeczeń sądowych oraz ich wykonywania w sprawach cywilnych i handlowych. Dz.Urz. L 351, 20.12.2012, s. 1-32.

${ }^{25}$ Motyw 4-5 Decyzji Rady 2014/887/WE...

${ }^{26}$ Artykuł 30 Konwencji o umowach dotyczących właściwości sądu.

${ }^{27}$ Decyzja Rady 2014/887/WE z dnia 4 grudnia 2014 r. w sprawie zatwierdzenia, w imieniu Unii Europejskiej, Konwencji haskiej z dnia 30 czerwca 2005 r. o umowach dotyczących właściwości sądu. Dz.Urz. L 353, 10.12.2014, s. 5-8.

${ }^{28}$ Komisja Europejska: Sprawozdanie Komisji dla Parlamentu europejskiego, Rady $i$ Europejskiego Komitetu Ekonomiczno-Spotecznego dotyczqce stosowania rozporzadzenia Rady (WE) nr 44/2001 w sprawie jurysdykcji i uznawania orzeczeń sqdowych oraz ich wykonywania $w$ sprawach cywilnych $i$ handlowych, COM/2009/0174 końcowy. Bruksela, 21 kwietnia 2009 r., s. 7.

${ }^{29}$ Artykuł 16 Konwencji haskiej z dnia 30 czerwca 2005 r. o umowach dotyczących właściwości sądu, COM/2014/046 final - 2014/0021. 
obowiązywania wymienionej Konwencji po brexicie ${ }^{30}$. Możliwe jednak, że nawet w przypadku zachowania ciagłości obowiazzywania Konwencji jedna ze stron umowy teoretycznie może powołać się na okoliczność brexitu, żądając niestosowania postanowień umowy przewidujących wyłączną jurysdykcję sądów brytyjskich w zmienionej pobrexitowej rzeczywistości. Doszło bowiem do istotnej zmiany otoczenia prawnego, w którym sąd brytyjski stał się sądem państwa trzeciego, gdy tymczasem w momencie przyjmowania postanowienia umownego $\mathrm{w}$ zakresie wyboru sądu był on jeszcze sądem jednego z państw członkowskich UE. Dodatkową okolicznością może być złożenie przez Zjednoczone Królestwo zastrzeżeń do wymienionej Konwencji, które to zastrzeżenia nie obowiązywały w czasie członkostwa tego państwa w UE. Na przykład 28 grudnia 2018 r. Zjednoczone Królestwo złożyło u depozytariusza Konwencji oświadczenie, że nie będzie stosować wymienionej Konwencji do umów ubezpieczenia, z wyjątkiem przypadków określonych w tym oświadczeniu ${ }^{31}$.

Ponadto z dniem wystąienia w Zjednoczonym Królestwie moga zaczaćc obowiązywać specyficzne zasady proceduralne typowe dla systemu common law, jak np. zakazy wnoszenia pozwu (ang. anti-suit injunctions). W wyroku w sprawie C-159/02 Turner Trybunał Sprawiedliwości potwierdził, że narzędzia proceduralne, które istnieją na mocy prawa krajowego i mogą wzmacniać skuteczność umów dotyczących jurysdykcji, takie jak zakazy wnoszenia pozwu (ang. anti-suit injunctions), sa niezgodne z rozporządzeniem Bruksela I, jeśli stanowią nieuzasadnioną przeszkodę w określaniu przez sądy innych państw członkowskich ich jurysdykcji na mocy rozporządzenia ${ }^{32}$. Z kolei w wyroku w sprawie C-185/07 Allianz SpA i in. v. West Tankers Inc. Trybunał Sprawiedliwości stwierdził, że wydanie wobec danej osoby przez są państwa członkowskiego zakazu wszczynania i dalszego prowadzenia postępowania przed sądami innego państwa członkowskiego, z tego względu, że takie postępowanie narusza zapis na sąd polubowny, jest niezgodne $\mathrm{z}$ rozporządzeniem Bruksela $\mathrm{I}^{33}$. Wskazane rozstrzygnięcia bywaja podawane jako jeden z powodów wy-

${ }^{30}$ Problem ten był przedmiotem zainteresowania mediów niedługo po referendum dotyczacym brexitu, np. E. Fennell: Brexit threat to courts. The Times, United Kingdom, 11/24/2016, s. 71.

31 Szczegóły: Hague Conference on Private International Law, Declaration/Reservation/Notification, https://www.hcch.net/en/instruments/conventions/status-table/notifica tions/?csid=1318\&disp=resdn [Dostęp: 25.10.2019 r.].

${ }^{32}$ Wyrok Trybunału (pełny skład) z dnia 27 kwietnia 2004 r. w sprawie C-159/02 Gregory Paul Turner przeciwko Felix Fareed Ismail Grovit, Harada Ltd i Changepoint SA. Zb. Orz. 2004 I-03565.

${ }^{33}$ Wyrok Trybunału (wielka izba) z dnia 10 lutego 2009 r. w sprawie C-185/07 Allianz SpA i Generali Assicurazioni Generali SpA przeciwko West Tankers Inc. ECLI:EU:C:2009:69. 
rażanej przez zwolenników brexitu woli pozbycia się zwierzchniej roli Trybunału Sprawiedliwości w wykładni prawa UE ${ }^{34}$. Tymczasem po brexicie sąd Zjednoczonego Królestwa może wydać zakaz wnoszenia pozwu w celu wzmocnienia umów dotyczących wyłącznego wyboru sądu na korzyść sądów w Wielkiej Brytanii, nawet jeśli jedna ze stron wniosła pozew sprzeczny z tą umowa w państwie członkowskim UE ${ }^{35}$. Sąd brytyjski będzie wówczas oczekiwać, że sąd państwa członkowskiego UE, podejmujac decyzję, czy odmówić jurysdykcji na rzecz wybranego sądu w Wielkiej Brytanii, zastosuje art. 6 Konwencji haskiej, a nie art. 31 ust. 2 rozporządzenia Bruksela I bis ${ }^{36}$. Z kolei w stosunku do umów zawartych przed brexitem sąd państwa członkowskiego może przystać na twierdzenia strony negującej skuteczność klauzuli prorogacyjnej ustanawiającej wyłączna jurysdykcję sądów brytyjskich ze względu na zmianę okoliczności wywołaną wystąpieniem Zjednoczonego Królestwa z Unii Europejskiej. Definitywne rozstrzygnięcie tej kwestii nie jest możliwe na tym etapie.

Brexit jest zjawiskiem wyjątkowym pod każdym względem, nawet jeśli chodzi o międzyczasowe stosowanie prawa. Co do zasady wymieniona Konwencja haska obowiązująca na mocy samodzielnego przystąpienia do niej Zjednoczonego Królestwa znajdzie zastosowanie do umów zawartych w dniu wystąienia lub później. Uwidocznienie różnicy między stosowaniem tej samej Konwencji w zależności od podstawy jej obowiązywania może okazać się istotne. Należy zaznaczyć, że Konwencja ta jest jednym $\mathrm{z}$ wielu aktów prawnych kształtujących system prawa UE $\mathrm{w}$ dziedzinie współpracy w sprawach cywilnych, tzn. nie funkcjonuje jako odseparowany od systemu prawa UE akt prawny. Tym samym stosowanie tej Konwencji w ramach systemu prawa UE odbywa się w innym otoczeniu prawnym niż w przypadku zastosowania tej samej Konwencji w wymianie z państwem trzecim, jakim stało się Zjednoczone Królestwo po brexicie. Może to oznaczać konieczność przeredagowania umów zawartych przed brexitem, w celu włączenia do nich umów klauzul wyłącznej jurysdykcji, lub konieczność zawarcia umowy uzupełniajacej w tym zakresie. Majac na uwadze pewność prawa, dobrze, by strony umowy pomyślały o tym przed upływem okresu przejściowego.

${ }^{34}$ M. Zachariasiewicz: Wptyw Brexitu na swobode przeptywu orzeczeń pomiędzy państwami UE $i$ Wlk. Brytania. Międzynarodowe prawo handlowe - Blog poświęcony aktualnościom i ciekawostkom z zakresu międzynarodowego prawa handlowego, prawa kolizyjnego i arbitrażu, https://miedzynarodoweprawohandlowe.wordpress. com/2017/05/11/wplyw-brexitu-na-swobode-przeplywu-orzeczen-pomiedzy-panstwamiue-i-wlk-brytania [Dostęp: 25.10.2019 r.].

${ }_{35}$ A. Mukarru m: BREXIT and English Jurisdiction Agreements: The Post-Referendum Legal Landscape. „European Business Law Review” 2016, 27, Issue 7, s. 990-997.

${ }^{36}$ A. Mukarrum, P. Beaumont: Exclusive Choice of Court Agreements..., s. 410. 


\section{Uznawanie i wykonywanie orzeczeń po wystąpieniu}

Współpraca sądowa $\mathrm{w}$ sprawach cywilnych stanowi obecnie niezależną i odrębną dziedzinę prawa $\mathrm{UE}^{37}$, co jest wynikiem wieloletniego rozwoju prawa $\mathrm{UE}^{38}$. Współpraca sądowa w sprawach cywilnych w UE opiera się na założeniach równej wartości, równych kompetencji i równych statusów systemów prawnych i sądowych poszczególnych państw członkowskich oraz orzeczeń ich sądów. Obowiązuje zasada wzajemnego zaufania do sądów i systemów prawnych funkcjonujących w pozostałych państwach. Wzajemne uznawanie orzeczeń sądowych przez państwa członkowskie $^{39}$ obejmuje m.in. koncepcję realizowania $\mathrm{w}$ praktyce transgranicznej współpracy między poszczególnymi sądami i organami sadowymi ${ }^{40}$. Celem jednolitych przepisów jest wspieranie pewności prawa i przewidywalności sytuacji prawnych mających skutki transgraniczne. W konsekwencji prawo prywatne międzynarodowe UE określa w jasny i kompleksowy sposób zasady ułatwiające uznawanie i wykonywanie orzeczeń sądowych wydanych przez państwo członkowskie. Po wystapieniu państwa z UE prawo prywatne międzynarodowe UE przestanie mieć zastosowanie $\mathrm{w}$ wymianie między tym państwem a państwami członkowskimi. Istotne są szczegóły, w jaki sposób się to odbędzie, dlatego instytucje UE publikuja wyjaśnienia w tym zakresie.

$\mathrm{W}$ przypadku instrumentów przewidujących procedurę exequatur możliwe są dwa scenariusze. Jeżeli orzeczenie sądu ze Zjednoczonego Królestwa zostało objęte procedura exequatur w jednym z państw członkowskich UE-27 przed datą wystapienia, ale nie zostało wykonane przed ta data, to orzeczenie takie może być nadal wykonywane w państwach UE-27. Fakt, że pierwotnie orzeczenie to było wydane przez sądy w Zjednoczonym Królestwie nie ma wówczas znaczenia. Jeśli chodzi o sprawy zawisłe w dniu wystąienia, to jeżeli przed dniem wystapienia orzeczenie sądu ze Zjednoczonego Królestwa nie zostało objęte procedurą exequatur, unijne przepisy dotyczace uznawania i wykonywania takich orzeczeń ze Zjednoczonego Królestwa nie będą miały zastosowania do orzeczenia sądu ze Zjednoczonego Królestwa, które nie zostało wykonane przed dniem wystąpienia, nawet jeśli orzeczenie wydano przed dniem wystapie-

${ }^{37}$ Rozdział 3: Wspótpraca sqdowa w sprawach cywilnych. Tytuł V: Przestrzeń wolności, bezpieczeństwa i sprawiedliwości Traktatu o funkcjonowaniu Unii Europejskiej.

38 A. Frąckowiak-Adamska: Uznawanie $i$ wykonywanie orzeczeń $w$ sprawach cywilnych w Unii Europejskiej - Ujęcie systemowe. Wolters Kluwer Polska, Warszawa, 2017, s. 39 i n.

${ }^{39}$ Artykuł 67 ust. 4 TFUE.

40 Artykuł 81 TFUE. 
nia lub procedury w celu wykonania orzeczenia rozpoczęto przed dniem wystąpienia. W odniesieniu do spraw wszczętych w dniu wystąpienia lub po tym dniu, w przypadku procedur majaccych na celu wykonanie orzeczenia sądu ze Zjednoczonego Królestwa, które to procedury rozpoczęły się od dnia wystąpienia w państwach UE-27, przepisy UE nie znajdą już zastosowania.

Analogicznie do jurysdykcji, uznawanie i wykonywanie orzeczeń będzie regulowane przez przepisy krajowe państwa członkowskiego uznania/ wykonania. W niektórych przypadkach zastosowanie znajdą konwencje międzynarodowe, w tym konwencje opracowane przez Haską Konferencję Prawa Prywatnego Międzynarodowego, z tym zastrzeżeniem, że zarówno Unia lub jej państwa członkowskie, jak i Zjednoczone Królestwo musza być stronami danej konwencji ${ }^{41}$. Konwencja z Lugano z 2007 r. o jurysdykcji i uznawaniu oraz wykonywaniu orzeczeń sądowych w sprawach cywilnych i handlowych ${ }^{42}$ mogłaby być w pewnym zakresie alternatywa dla rozporządzeń brukselskich. Stanowi ona obecnie podstawę do wzajemnego wykonywania orzeczeń między państwami członkowskimi Unii Europejskiej a trzema krajami Europejskiego Stowarzyszenia Wolnego Handlu (EFTA) - Szwajcaria, Norwegia i Islandia. Zjednoczone Królestwo, występując z Unii, przestanie być stroną tej Konwencji, dlatego też powinno rozważyć przystąpienie do Konwencji z Lugano.

Należy zaznaczyć, że Konwencja z Lugano jest otwarta do przystapienia dla państw, które staną się członkami Europejskiego Stowarzyszenia Wolnego Handlu ${ }^{43}$ lub państwami członkowskimi UE. Zjednoczonemu Królestwu pozostanie jedynie możliwość przystapienia do Konwencji z Lugano przez uprzednie przystapienie do EFTA. Warto przypomnieć, że Zjednoczone Królestwo przystapiło do rozporzadzeń brukselskich świadomie, ponieważ każdorazowo powiadamiało o chęci uczestniczenia $\mathrm{w}$ przyjęciu i stosowaniu rozporządzenia Bruksela I i Bruksela I bis ${ }^{44}$, co wynika z faktu, że Zjednoczone Królestwo nie $\mathrm{w}$ pełni uczestniczyło $\mathrm{w}$ integracji $\mathrm{w}$ ramach Przestrzeni Wolności, Bezpieczeństwa i Sprawiedliwości ${ }^{45}$. Jak dotąd rząd Zjednoczonego Kró-

${ }^{41}$ Komisja Europejska - Dyrekcja Generalna ds. Sprawiedliwości i Konsumentów: Zawiadomienie dla zainteresowanych stron - Wystapienie Zjednoczonego Królestwa z UE a przepisy UE $w$ dziedzinie wymiaru sprawiedliwości $w$ sprawach cywilnych $i$ prawa prywatnego międzynarodowego..., s. 2-3.

${ }^{42}$ Konwencja o jurysdykcji i uznawaniu oraz wykonywaniu orzeczeń sądowych w sprawach cywilnych i handlowych. Dz.Urz. UE L 339, 21.12.2007, s. 3-41.

${ }_{43}$ Artykuł 70 ust. 1 pkt a Konwencji o jurysdykcji i uznawaniu oraz wykonywaniu orzeczeń sądowych w sprawach cywilnych i handlowych, s. 3-41.

${ }_{44}$ Motyw 40 rozporządzenia 1215/2012.

${ }_{45}$ Tytuł V: Przestrzeń wolności, bezpieczeństwa i sprawiedliwości Traktatu o funkcjonowaniu Unii Europejskiej. 
lestwa nie przejawia woli wydłużenia $\mathrm{w}$ czasie stosowania rozporzadzenia Bruksela I bis ani woli przystąpienia do Konwencji z Lugano. Tymczasem nietrudno jest przewidzieć, w jaki sposób brak skutecznej jurysdykcji i egzekwowania systemu orzeczeń między UE a Zjednoczonym Królestwem zaszkodzi atrakcyjności Anglii i Walii jako miejsca rozstrzygania sporów transgranicznych ${ }^{46}$. Podobne wnioski można wysnuć w odniesieniu do rozporządzeń rzymskich, które przestaną być stosowane przez sądy brytyjskie. W doktrynie pojawiły się twierdzenia, że jeżeli nie uda się osiagnąć odpowiedniego porozumienia w ramach umowy o wystąpieniu, to Wielka Brytania powinna podjać decyzję o jednostronnym stosowaniu rozporządzeń Rzym I i Rzym II ${ }^{47}$. Rozwiąanie to wydaje się zasadne z punktu widzenia pewności prawa i atrakcyjności sądów brytyjskich w sprawach transgranicznych. Już jednak wiadomo, że jak chodzi o prawo właściwe, to reżim rzymski w Zjednoczonym Królestwie nie będzie stosowany, a przynajmniej częściowo się zmieni moca prawa brytyjskiego, w konsekwencji czego powstanie ryzyko niepewności prawnej, szczególnie w odniesieniu do stosunków umownych ${ }^{48}$.

\section{Współpraca sądowa w sprawach cywilnych po wystąpieniu}

Prawo Unii wprowadza ułatwienia we współpracy sądowej w sprawach cywilnych. Dotyczą one doręczania dokumentów ${ }^{49}$, przeprowadzania dowodu ${ }^{50}$ czy funkcjonowania europejskiej sieci sądowej w sprawach

${ }^{46}$ S. Gabriel, S. Giroud, B. Mauron, V. Meerovich: Brexit: A New Era for Recognition and Enforcement of English Judgments in Europe or Turning Back the Clock? Lessons to Be Learned From the Swiss Example. „Dispute Resolution International” May 2019, vol. 13, no. 1, s. 86.

${ }^{47}$ G. Rühl: Judicial Cooperation in Civil and Commercial Matters after BREXIT..., s. $99-128$.

48 J. Ungerer: Consequences of Brexit for European Private International Law. „European Papers” 2019, vol. 4, no. 1, „European Forum”, Insight of 27 February 2019, s. 395-407, doi: 10.15166/2499-8249/281 [Dostęp: 25.10.2019 r.].

${ }_{49}$ Rozporządzenie nr 1393/2007 Parlamentu Europejskiego i Rady z dnia 13 listopada 2007 r. dotyczące doręczania w państwach członkowskich dokumentów sądowych i pozasądowych w sprawach cywilnych i handlowych (doręczanie dokumentów) oraz uchylajacce rozporządzenie Rady (WE) nr 1348/2000. Dz.Urz. UE L 324, 10.12.2007, s. 79-120.

${ }^{50}$ Rozporządzenie Rady (WE) nr 1206/2001 z dnia 28 maja 2001 r. w sprawie współpracy między sądami Państw Członkowskich przy przeprowadzaniu dowodów w sprawach cywilnych lub handlowych. Dz.Urz. UE L 174, 27.06.2001, s. 1-24. 
cywilnych i handlowych ${ }^{51}$. Począwszy od dnia wystąienia państwa członkowskie UE-27 nie będą kontynuować toczących się procedur współpracy sądowej z udziałem Zjednoczonego Królestwa. Analogicznie, nie będą rozpoczynać nowych procedur współpracy sądowej z udziałem Zjednoczonego Królestwa na podstawie prawa UE, takie procedury bowiem moga być kontynuowane jedynie zgodnie z prawem krajowym dotyczacym współpracy sądowej z państwami trzecimi. Również w tym zakresie w niektórych przypadkach zastosowanie znajdą konwencje międzynarodowe, takie jak konwencje opracowane przez Haską Konferencję Prawa Prywatnego Międzynarodowego, pod warunkiem, że zarówno UE lub jej państwa członkowskie, jak i Zjednoczone Królestwo są stronami danej konwencji.

Przykładem takiej konwencji może być Konwencja haska z 1980 r. dotycząca cywilnych aspektów uprowadzenia dziecka za granicę. W stosunkach między państwami członkowskimi UE pierwszeństwo stosowania przed wymieniona Konwencją ma rozporządzenie 2201/2003 dotyczące jurysdykcji oraz uznawania i wykonywania orzeczeń w sprawach małżeńskich oraz $\mathrm{w}$ sprawach dotyczących odpowiedzialności rodzicielskiej. Rozporządzenie to ma zastosowanie w państwach członkowskich UE, w tym w Zjednoczonym Królestwie, od 1 marca 2005 r. Zakończenie obowiązywania wymienionego rozporządzenia nastąpi 31 lipca 2022 r., kiedy to zostanie ono zastapione rozporządzeniem 2019/1111 z dnia 25 czerwca 2019 r. w sprawie jurysdykcji, uznawania i wykonywania orzeczeń w sprawach małżeńskich i w sprawach dotyczących odpowiedzialności rodzicielskiej oraz w sprawie uprowadzenia dziecka za granice $^{52}$. Zjednoczone Królestwo powiadomiło o chęci uczestniczenia w przyjęciu i stosowaniu nowego rozporządzenia ${ }^{53}$, co nastąpiło już po referendum dotyczącym wystąpienia z UE. Uzasadnienie powyższej decyzji Zjednoczonego Królestwa może stanowić pewną wskazówkę co do przyszłych relacji w zakresie współpracy sądowej między sądami brytyjskimi a sądami państw członkowskich po brexicie.

Brytyjski Minister ds. Sądownictwa i Sprawiedliwości, odnosząc się do wniosku Komisji w sprawie projektu rozporządzenia 2019/1111, stwierdził w dniu 27 października 2016 r., że niezależnie od wyniku referendum w sprawie członkostwa w UE rząd uważa, że włączenie się do

${ }^{51}$ Decyzja Rady z dnia 28 maja 2001 r. ustanawiająca Europejską Sieć Sądowa w sprawach cywilnych i handlowych. Dz.Urz. UE L 174, 27.06.2001, s. 25-31.

${ }_{52}$ Rozporządzenie Rady (UE) 2019/1111 z dnia 25 czerwca 2019 r. w sprawie jurysdykcji, uznawania i wykonywania orzeczeń w sprawach małżeńskich i w sprawach dotyczacych odpowiedzialności rodzicielskiej oraz w sprawie uprowadzenia dziecka za granicę (wersja przekształcona), ST/8214/2019/INIT. Dz.Urz. UE L 178, 2.07.2019, s. 1—115.

${ }_{53}$ Motyw 95 rozporządzenia 2019/1111. 
tej propozycji leży w interesie Wielkiej Brytanii ${ }^{54}$. Minister wyjaśniał wówczas, że Wielka Brytania stosuje przepisy rozporządzenia 2201/2003 z korzyścią dla obywateli brytyjskich, w tym dzieci w rodzinach przygranicznych. Przestrzegał, że należy uniknąć ryzyka, że jeśli nowe rozporządzenie wejdzie w życie przed brexitem, a Zjednoczone Królestwo nie zdecyduje się na przyjęcie nowego rozporządzenia, to rozporządzenie 2201/2003 nie będzie już miało zastosowania do Wielkiej Brytanii, ponieważ przestanie obowiazywaćs ${ }^{55}$. Tym samym przez pewien czas żaden instrument UE nie regulowałby tych kwestii w stosunku do brytyjskich rodzin, mimo że Wielka Brytania byłaby nadal państwem członkowskim. Dodatkowo, nawet po wyjściu z Unii rozporządzenie wpłynie na obywateli brytyjskich zamieszkałych w innych państwach członkowskich.

W konsekwencji po wystapieniu Zjednoczonego Królestwa z Unii alternatywą dla rozporządzenia unijnego stanie się Konwencja haska dotycząca cywilnych aspektów uprowadzenia dziecka za granicę. Wszystkie państwa członkowskie Unii są stronami Konwencji haskiej z 1980 r., w tym Zjednoczone Królestwo. Wystapienie Zjednoczonego Królestwa z Unii Europejskiej nie powinno wpłynacc na stosowanie wymienionej Konwencji między Zjednoczonym Królestwem a państwami członkowskimi UE. W doktrynie pojawiały się argumenty, że w braku szczególnych ustaleń w tym względzie po brexicie Konwencja znajdzie natychmiastowe zastosowanie między Zjednoczonym Królestwem a wszystkimi państwami członkowskimi UE, ponieważ Zjednoczone Królestwo przystąpiło do tej Konwencji 20 maja 1986 r. jako państwo członkowskie UE ${ }^{56}$. Wniosek ten jest prawidłowy, mimo że materia uregulowana wymieniona Konwencją należy do kompetencji wyłącznych Unii, tym samym o ewentualnym przystępowaniu nowych państw do tej Konwencji decyduje Rada Unii Europejskiej w odniesieniu do relacji między państwem trzecim a państwami członkowskimi UE.

Trybunał Sprawiedliwości wypowiedział się na temat podziału kompetencji w procesie przystępowania do Konwencji haskiej z 1980 r. Przystąpić do tej Konwencji może każde państwo, ale przystąpienie będzie skuteczne tylko w stosunkach między państwem przystępującym a tymi

${ }_{54}$ T. Jarrett: Brexit: the Brussels IIa regulation - cross-border child contact cases, and child abduction, House of Commons Library, briefing paper, Number 07764, 11 November 2016, https://researchbriefings.parliament.uk/ResearchBriefing/Summary/ CBP-7764 [Dostęp: 25.10.2019 r.], s. 4.

${ }^{55} \mathrm{~W}$ chwili przedstawiania stanowiska na ten temat nie było jeszcze wiadomo, że rozporządzenie 2201/2003 przestanie obowiązywać w dniu 31 lipca $2022 \mathrm{r}$.

${ }^{56}$ P. Beaumont: Interaction of the Brussels IIa and Maintenance Regulations with [possible] litigation in nonEU States: Including Brexit Implications. Working Paper No. 2018/1, https://www.abdn.ac.uk/law/research/working-papers-455.php [Dostęp: 25.10.2019 r.], s. 11. 
umawiającymi się państwami, które złożą oświadczenie o wyrażeniu zgody na to przystapienie ${ }^{57}$. Wyrażenie zgody na przystąpienie państwa trzeciego do wymienionej Konwencji należy do wyłącznej kompetencji Unii, Konwencja bowiem reguluje sprawy uregulowane wtórnym prawem UE, a konkretnie rozporządzeniem 2201/2003. Rozporządzenie ma wprawdzie pierwszeństwo przed wymieniona Konwencją w zakresie, $\mathrm{w}$ jakim dziedziny uregulowane $\mathrm{w}$ tych dwóch aktach nakładaja się na siebie $^{58}$, ale mimo to nieskoordynowane wyrażanie przez państwa członkowskie zgody na przystapienie państw trzecich do Konwencji haskiej z 1980 r. stwarza ryzyko wywarcia wpływu na zakres i skuteczność wspólnych zasad ustanowionych wymienionym rozporządzeniem. Wyrażanie przez państwa samodzielnie zgody lub jej odmowy na przystapienie nowego państwa stwarzałoby ryzyko wpływu na jednolite i spójne stosowanie rozporządzenia nr 2201/2003, a zwłaszcza na zasady współpracy między organami państw członkowskich w każdym przypadku, gdy sytuacja polegająca na uprowadzeniu dziecka za granicę dotyczyłaby jednego państwa trzeciego i dwóch państw członkowskich, z których jedno wyraziło zgodę na przystąpienie tego państwa trzeciego, a drugie takiej zgody nie wyraziło ${ }^{59}$. Wpływ zobowiązań międzynarodowych na zasady Unii może mieć miejsce również wtedy, gdy brak jest między nimi sprzeczności ${ }^{60}$. Z tych względów wyrażenie zgody na przystąienie państwa trzeciego do Konwencji haskiej z 1980 r. należy do wyłącznej kompetencji Unii i każdorazowo wydawane są decyzje upoważniające państwa członkowskie do wyrażenia zgody na przystąpienie państwa trzeciego do wymienionej Konwencji ${ }^{61}$. W rezultacie po brexicie bez szczególnych postanowień umownych współpraca sądowa między Zjednoczonym Królestwem a państwami członkowskimi UE w sprawach cywilnych dotyczących uprowadzenia dziecka za granicę będzie odbywać się na podstawie Konwencji haskiej z 1980 r., ale bez wzmocnienia, jakim było unijne rozporządzenie regulujące tę kwestię.

${ }^{57}$ Artykuł 38 Konwencji dotyczącej cywilnych aspektów uprowadzenia dziecka za granicę sporządzonej w Hadze 25 października 1980 r. Dz.U. 1992, nr 108, poz. 528.

58 Artykuł 60 rozporządzenia 2201/2003.

${ }_{59}$ Opinia Trybunału (wielka izba) z dnia 14 października 2014 r. nr 1/13, pkt. 8690. ECLI:EU:C:2014:2303.

${ }^{60}$ Opinia Trybunału z dnia 19 marca 1993 r. nr 2/91, pkt. 25-26. ECLI:EU:C: 1993:106.

${ }^{61}$ Tytułem przykładu: Decyzja Rady (UE) 2015/2358 z dnia 10 grudnia 2015 r. upoważniająca niektóre państwa członkowskie do wyrażenia zgody, w interesie Unii Europejskiej, na przystąienie Armenii do Konwencji haskiej z 1980 r. dotyczacej cywilnych aspektów uprowadzenia dziecka za granicę. Dz.Urz. UE L 331, 17.12.2015, s. 23-25. 


\section{Inne aspekty przestrzeni wolności, bezpieczeństwa i sprawiedliwości}

Przestrzeń wolności, bezpieczeństwa i sprawiedliwości w Unii Europejskiej obejmuje znacznie więcej aspektów niż systemowe rozwiązania odnoszące się do jurysdykcji oraz uznawania i wykonywania orzeczeń, ale ich analiza wykracza poza ramy niniejszego artykułu. Możliwe jest jedynie wskazanie skutków brexitu w wybranych aspektach integracji europejskiej w tym obszarze. Chodzi przede wszystkim o szczególne procedury unijnego prawa jednolitego czy los portalu e-Sprawiedliwość i interaktywnych formularzy po wystapieniu. W prawie UE dotyczącym współpracy sądowej w sprawach cywilnych przewidziano szczególne procedury, takie jak europejski nakaz zapłaty ${ }^{62}$ czy europejskie postępowanie $\mathrm{w}$ sprawie drobnych roszczeń ${ }^{63}$. Przedstawione wyżej zasady dotyczące jurysdykcji oraz uznania i wykonania orzeczeń maja zastosowanie również do tego rodzaju szczególnych procedur, tzn. Zjednoczone Królestwo stało się państwem trzecim, a akty prawa UE wprowadzajace wyżej wymienione szczególne procedury przestaną mieć zastosowanie z upływem okresu przejściowego ${ }^{64}$.

Komisja Europejska udostępnia różne narzędzia informacyjne na temat krajowego systemu sądowego za pośrednictwem portalu e-Sprawiedliwośćc5. Aktualnie portal ten zawiera interaktywne formularze we wszystkich językach urzędowych UE. Formularze dotycza: europejskiego nakazu zapłaty, dochodzenia roszczeń drobnych, rekompensaty dla ofiar przestępstw, europejskiego tytułu egzekucyjnego, orzeczeń w sprawach cywilnych i handlowych, pomocy prawnej, zobowiazzań alimentacyjnych, spraw małżeńskich i z zakresu odpowiedzialności rodzicielskiej, doręczania dokumentów, przeprowadzenia dowodu w sprawach cywilnych i handlowych, europejskiego poświadczenia spadkowego, europejskiego nakazu zabezpieczenia na rachunku bankowym czy wzajemnego uzna-

${ }^{62}$ Rozporządzenie (WE) nr 1896/2006 Parlamentu Europejskiego i Rady z dnia 12 grudnia 2006 r. ustanawiające postępowanie w sprawie europejskiego nakazu zapłaty. Dz.Urz. UE L 399, 30.12.2006, s. 1-32.

${ }^{63}$ Rozporządzenie (WE) nr 861/2007 Parlamentu Europejskiego i Rady z dnia 11 lipca 2007 r. ustanawiajacce europejskie postępowanie w sprawie drobnych roszczeń. Dz.Urz. UE L 199, 31.07.2007, s. 1-2.

${ }^{64}$ Komisja Europejska - Dyrekcja Generalna ds. Sprawiedliwości i Konsumentów: Zawiadomienie dla zainteresowanych stron - Wystapienie Zjednoczonego Królestwa $z$ UE a przepisy UE $w$ dziedzinie wymiaru sprawiedliwości $w$ sprawach cywilnych $i$ prawa prywatnego międzynarodowego..., s. 4-5.

${ }_{65}$ Zob. https://e-justice.europa.eu/home.do?action=home\&plang=pl. 
wania środków ochrony. Wybierając w portalu e-Sprawiedliwość jedno z dostępnych postępowań, można jednocześnie wybrać kraj, by uzyskać informacje na temat treści prawa danego państwa członkowskiego w zakresie wcześniej wybranego aspektu (ikony z flagami po prawej stronie). Jest to doskonałe narzędzie ułatwiające ustalenie zarówno jurysdykcji, jak i prawa właściwego oraz jego treści. Od dnia wystapienia portal e-Sprawiedliwość nie będzie już zawierał informacji dotyczących Zjednoczonego Królestwa, w tym interaktywnych formularzy i zestawień informacji na temat Zjednoczonego Królestwa ${ }^{66}$. W rzeczywistości zestawienia informacji o sądach brytyjskich i prawie brytyjskim mogłyby być użyteczne także po brexicie, ale planuje się ich usunięcie wraz z zakończeniem okresu przejściowego. Jest to naturalna konsekwencja brexitu, ponieważ zawarte $\mathrm{w}$ portalu e-Sprawiedliwość informacje zdezaktualizują się z upływem okresu przejściowego, a Zjednoczone Królestwo nie będzie miało obowiązku ich aktualizowania po wystąpieniu, ponieważ z przyczyn oczywistych nie będzie uczestnikiem współpracy sądowej w ramach UE.

\section{Wnioski}

Integracja europejska przyniosła Europie pokój i dobrobyt oraz umożliwiła niespotykaną wcześniej współpracę, nie tylko w zakresie wymiaru sprawiedliwości $\mathrm{w}$ sprawach cywilnych czy prawa prywatnego międzynarodowego, ale we wszystkich kwestiach będących przedmiotem wspólnego zainteresowania ${ }^{67}$. Analiza skutków wystapienia Zjednoczonego Królestwa z Unii Europejskiej w zakresie określonym w tytule niniejszego artykułu prowadzi do wniosku, że wraz z wystapieniem państwo i jego obywatele przestaja korzystać ze wspólnego dorobku prawnego gwarantujacego daleko idace udogodnienia w sprawach $\mathrm{z}$ elementem obcym. Generalnie Zjednoczone Królestwo stało się państwem trzecim w rozumieniu przepisów prawa UE w dziedzinie wymiaru sprawiedliwości w sprawach cywilnych i prawa prywatnego międzynarodowego $\mathrm{z}$ za-

${ }^{66}$ Komisja Europejska - Dyrekcja Generalna ds. Sprawiedliwości i Konsumentów: Zawiadomienie dla zainteresowanych stron - Wystapienie Zjednoczonego Królestwa $z$ UE a przepisy UE $w$ dziedzinie wymiaru sprawiedliwości $w$ sprawach cywilnych $i$ prawa prywatnego międzynarodowego..., s. 5.

${ }_{67}$ Rada Europejska, Wytyczne opracowane w następstwie notyfikacji złożonej przez Zjednoczone Królestwo na mocy art. 50 TUE, s. 2. 
strzeżeniem okresu przejściowego. W niektórych sprawach zastosowanie znajdą konwencje międzynarodowe, w tym w szczególności konwencje opracowane przez Haską Konferencję Prawa Prywatnego Międzynarodowego, o ile zarówno Unia Europejska lub jej państwa członkowskie, jak i Zjednoczone Królestwo są stronami danej konwencji. W konsekwencji relacja Zjednoczonego Królestwa i Unii Europejskiej bywa porównywana do miłości, która przeminęła, a byli kochankowie muszą się nadal spotykać od czasu do czasu, by załatwić pewne wspólne sprawy. Analiza tematu prowadzi do wniosku, że w istocie brexit jest zjawiskiem unikatowym, które nie ma żadnej wartości dodanej.

\section{Bibliografia}

Beaumont P.: Interaction of the Brussels IIa and Maintenance Regulations with [possible] litigation in nonEU States: Including Brexit Implications. Working Paper No. 2018/1, https://www.abdn.ac.uk/law/research/workingpapers-455.php [Dostęp: 25.10.2019 r.].

Fennell E.: Brexit threat to courts. The Times, United Kingdom, 11/24/2016.

Frąckowiak-Adamska A.: Uznawanie $i$ wykonywanie orzeczen $w$ sprawach cywilnych w Unii Europejskiej - Ujęcie systemowe. Wolters Kluwer Polska, Warszawa, 2017.

Gabriel S., Giroud S., Mauron B., Meerovich V.: Brexit: A New Era for Recognition and Enforcement of English Judgments in Europe or Turning Back the Clock? Lessons to Be Learned From the Swiss Example. „Dispute Resolution International" May 2019, vol. 13, no. 1.

Garner O.: After Brexit: Protecting European Citizens and Citizenship from Fragmentation (2016), European University Institute Department of Law Working Paper No. 2016/22. Available at SSRN, https://ssrn.com/abstract=2871404 or http://dx.doi.org/10.2139/ssrn.2871404 [Dostęp: 25.10 .2019 r.].

Jarrett T.: Brexit: the Brussels IIa regulation - cross-border child contact cases, and child abduction, House of Commons Library, briefing paper, Number 07764, 11 November 2016, https://researchbriefings.parliament.uk/ ResearchBriefing/Summary/CBP-7764 [Dostęp: 25.10.2019 r.].

Mukarrum A.: BREXIT and English Jurisdiction Agreements: The Post-Referendum Legal Landscape. „European Business Law Review” 2016, 27, Issue 7.

Mukarrum A., Beaumont P.: Exclusive Choice of Court Agreements: Some Issues on the Hague Convention on Choice of Court Agreements and Its Relationship with the Brussels I Recast Especially Anti-Suit Injunctions, Concurrent Proceedings and the Implications of BREXIT. „Journal of Private 
International Law" vol. 13, no. 2, Aug. 2017, s. 386-410. EBSCOhost, doi: 10.1080/17441048.2017.1348782 [Dostęp: 25.10.2019 r.].

Półtorak N.: Rola Unii Europejskiej w kształtowaniu wspótczesnego prawa prywatnego międzynarodowego. „Kwartalnik Prawa Prywatnego” 2019, z. $28 / 2$.

Rühl G.: Judicial Cooperation in Civil and Commercial Matters after BREXIT: Which Way Forward? „International and Comparative Law Quarterly” 2016, 67(1), 99—128, doi:10.1017/S0020589317000574 [Dostęp: 25.10.2019 r.].

Ungerer J.: Consequences of Brexit for European Private International Law. „European Papers” 2019, vol. 4, no. 1, „European Forum”, Insight of 27 February 2019, s. 395—407, doi: 10.15166/2499-8249/281 [Dostęp: 25.10.2019 r.].

Zachariasiewicz M.: Wptyw Brexitu na swobode przeptywu orzeczeń pomiędzy państwami UE $i$ Wlk. Brytaniq. Międzynarodowe prawo handlowe - Blog poświęcony aktualnościom i ciekawostkom z zakresu międzynarodowego prawa handlowego, prawa kolizyjnego i arbitrażu, https:// miedzynarodoweprawohandlowe.wordpress.com/2017/05/11/wplyw-brexituna-swobode-przeplywu-orzeczen-pomiedzy-panstwami-ue-i-wlk-brytania [Dostęp: 25.10.2019 r.]. 